The International Journal of Urologic History@ www.ijuh.org

\title{
The BCG disaster, Lübeck, 1930: An Oral History Project of the 'Calmette Children' and their Survivorship
}

\author{
Hanna Lohse \\ From the Universitätsklinik für Kinder- und Jugendmedizin, Evangelisches Klinikum, Bethel, Germany \\ Correspondence: Burgsteig 13, 33617 Bielefeld, Germany; email: hanna.lohse@gmx.net
}

Introduction: Today Bacillus Calmette Guérin (BCG) is the most common agent used in the intravesical treatment of nonmuscle invasive (NMIBC) bladder cancer but originally was used as a vaccine against the widespread scourge of tuberculosis. The public acceptance of this vaccination was, at least in Germany, delayed by an infamous 1930 medical event in which 251 infants were accidentally inoculated with a batch of BCG vaccine contaminated with live mycobacterial cultures. The accident itself was comprehensively investigated but those affected were forgotten. For this oral history project, adult survivors of the 1930 BCG disaster were interviewed in order to document their biographical outcomes and personal perspectives.

Sources and Methods: We conducted personal, recorded interviews with identified survivors of the 1930 BCG accident and relatives. We analyzed contemporary news articles and accounts and secondary sources from German medical and popular literature.

Results: Of the survivors, a total of 8 patients and 8 family members of patients were interviewed. In addition, two interviews were also conducted with relatives of the presiding judge from the 1931/2 trial and of an involved physician. The 18 biographies make up the dataset for this study. Interviewed survivors, the so called 'Calmette Kinder' (Ger."Kinder": Children), recounted years of illness and chronic health impairments. The supportive measures taken after the accident by the town of Lübeck were extensive and ranged from medical care and health promoting measures such as additional food for the vaccinated infants to the establishment of an arbitration court for the compensation of the 'Calmette Kinder'.

Conclusions: The Lübeck Disaster was a landmark event in the history of biomedical safety, ethics and informed consent. The decades-long consequences of a failed vaccination effort for infants still urges a cautious, measured approach to medical progress today. Lessons learned were critical for the establishment of the modern approach to public vaccination efforts so well-illustrated in the fight against CoVid 19 and other microbiological threats.

Keywords: BCG, ethics, vaccine safety, Lübeck, oral history

$\mathrm{O}$ Sunday morning, the 6th of July, our beloved little Günther died after eight weeks of severe illness at the age of 16 weeks of the horrific effects of the Calmette vaccination. With greatest pain we mourn the death of our promising child, on whom doctors performed a dangerous experiment without our knowledge."(1)

Thus write the devastated parents of a child, lost in the summer of 1930 a few weeks after receiving an oral dose of BCG accidentally contaminated with virulent mycobacterium tuberculosis in Lübeck, Germany. Lübeck, a coastal town on the Baltic Sea, was supposed to become a pioneer in the fight against

International Journal of Urology@ 2021 the widespread disease of tuberculosis. Instead, the city became the scene of the greatest vaccination disaster in the 20th century, the so-called "Lübecker Impfunglück" (Ger.: "Impf.", vaccination; "unglück", accident). The oral vaccine was composed of the so-called "bacillus Calmette-Guérin": After 15 years of work, and wholly stopped by World War I, Albert Calmette (1863-1933) and Camille Guérin (1872-1961) finally produced an attenuated strain of mycobacterium bovis that was effective as an oral vaccine against mycobacterium tuberculosis and was first used in France in 1924 (figure 1).(2) Five years later, two Lübeck physicians, who had long been dedicated to fighting tuberculosis, planned the first introduction of BCG in Germany. In 1929, a 
culture of BCG was sent from the Pasteur Institute in Paris to a local Lübeck laboratory where the BCG was further cultivated.(3) The lab was headed by a Professor F.G.B. Deycke, Director of the local General Hospital. In the Deycke laboratory, different analyses were also carried out, among which were tests with virulent tuberculosis bacteria. After the approval of the medical staff and local government officials, a public vaccination campaign officially started on February 24, 1930. In total, 251 infants (over 60\% of all newborns in Lübeck) were inoculated.(4) By March 1930, some of the infants presented with nonspecific symptoms like vomiting or tiredness. A month later, infants developed severe illnesses including protracted vomiting, rashes, swollen lymph nodes, pneumonia, failure to thrive, and cachexia. Hospitalizations increased to a daily occurrence at which point some parents and their pediatricians suspected a connection between the 'vaccination' event and the child illnesses.

By the end of April, 1930, three infants had succumbed to their diseases. At the autopsy of the third child on April 26th, 1930, gastrointestinal tuberculosis was detected and the connection between the vaccinations and the previously inexplicable illnesses was finally discovered. The production of any further vaccines in the Deycke laboratory was stopped and remains were destroyed. Vaccines that had already been distributed, however, were not reclaimed, and some children received the second and third vaccine doses until April 30th. Initial presumptions were that the toxic doses were limited to a single day's vaccinations but this was disproved in the following days by illnesses of children vaccinated with different productions. On May 14 th, or nearly three months after the vaccination effort had begun, the public was finally informed about the disaster. Following this announcement Lübeck became the focus of international public attention. Even major journals such as The Lancet and the Journal of the American Medical Association reported on the Lübeck disaster and the subsequent trials of the medical staff involved with the vaccine production.(5-7) Albert Calmette himself took the news badly. While the BCG vaccine and the Pasteur Institute were exonerated early in the discovery process, Calmette's health precipitously declined and he was dead by 1933.(8) Regardless of the exoneration, BCG vaccination was not used again in Germany until after the Second World War.(9)

After a long, internal investigation, the so-called 'Calmette trial' was held for nearly four months from October 1931 to February 1932 in a local gymnasium

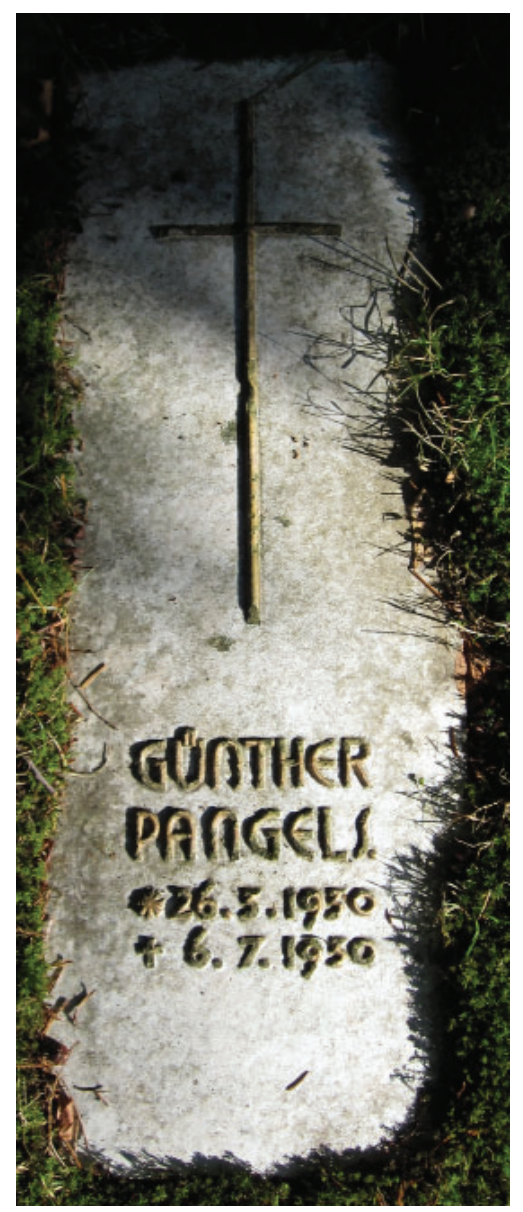

Figure 1. (Left) Albert Calmette (lefT), co-developer of BCG, in a staged photo, showing the then recommended practice of oral inoculation of the newborn to protect against TB (National Library of France). Figure 2. (Right) Gravestone of the infant of the Pangels family in a Lübeck, Germany cemetery (photography: H. Lohse) 
because courtrooms proved to be too small. Numerous experts on bacteriology and tuberculosis were called to testify. Possible causes of the accident were proposed included a reversion of the attenuated BCG back to its original virulence. It was quickly concluded, however, that the BCG vaccine cultures were accidentally mixed with a strain of human tuberculosis bacteria stored in the same rooms at the Deycke laboratory. The two Lübeck physicians who had organized the vaccination campaign were convicted to prison sentences for offenses of involuntary manslaughter and involuntary bodily injury. Professor Deycke received a two year sentence and Dr. Altstaedt, medical head of the Health Department, one year and three months. The laboratory nurse, Anna Schütze, was acquitted for lack of evidence. It was never concluded exactly how the BCG vaccine became contaminated by the infectious mycobacterial cultures.

While the verdicts ended the legal aspects of the disaster, the clinical and sociological aspects continued in the survivors and their families for 80 years. There has been no study of their outcomes and the long-term impact of the Lübeck disaster on the so-called 'Calmette Kinder' (Ger. "Kinder": children). Therefore, an oral history project, "Contemporary witnesses of the Lübeck disaster", was established to close the knowledge gap and provide a human portrait of the effects of a public health campaign gone wrong.

\section{SOURCES AND METHODS}

Interviews with vaccinated persons or those related to them built the basis for this oral history project. After a search for witnesses, via a local newspaper article and other outreach efforts, eight interviews with survivors, eight with relatives of survivors, and two with relatives of Dr. Altstaedt and the chief judge of the trial, Heinrich Wibel, were conducted between 2011 and 2012. During the interviews, the author was also provided with various personal documents related to the disaster. The 18 interviews were semi-structured. Following an open beginning, a pre-developed interview guideline was used to allow comparability between sets and ensure a standard coverage of topics. $(10,11)$ The interviews were recorded and then transcribed verbatim. Their evaluation was based on previously published methodologies to summarize qualitative content analysis. In this way, 18 datasets were created, in which the life stories of the sufferers were presented along a timeline. The repeated analysis of all transcripts, biographs, and personal and generally accessible archival documents established overarching themes. For background information, contemporary literature, newspaper articles, and secondary resources were used.

\section{RESULTS}

\section{Damage Control}

No anti-mycobacterial chemotherapeutic agents were known or available in 1930 to treat children acutely infected with $\mathrm{m}$. tuberculosis. The prevailing wisdom was to treat tubercular symptoms and strengthen the natural defenses. Medical experts from Hamburg were called to Lübeck and a panel with local physicians was arranged in May 1930.(12) An immediate evaluation and overview of all vaccinated children including serial examinations and radiographs were started. After the announcement of the disaster in May 1930, new victims were reported almost daily in the local newspapers. There was great concern in Lübeck that all 'Calmette Kinder' would eventually suffer the fate of contracting tuberculosis. In the first serial examinations of July 1930 , it was concluded, however, that not all vaccinated infants became critically ill and that some children even showed no or few symptoms. In a subsequent investigation of the disaster, it was found that the productions of vaccine from different days had contained different amounts of BCG and virulent tuberculosis bacteria thus accounting for the variation in acquired illness severity. The findings helped to disprove the fear that eventually all vaccinated children would succumb to infection. Still, most of the 72 infants who died, did so at the ages of between three and four months old, between May and July 1930, and the last death occurred in April 1931. The 174 survivors were subsequently $x$-rayed in a serial exam fashion in 1932 and 1933. A total of 126/174 (72.4\%) showed calcified abdominal lymph nodes which was a marker of active tuberculosis infection.(4) Among the surviving children, clinical tuberculosis remained active in some cases until the age of three or four and in some cases caused permanent damages like (mostly unilateral) deafness, as follows.(13)

\section{Lifelong health impairments}

One of the Project interviewees was nine years old when her brother fell ill with tuberculosis from the contaminated BCG vaccine at the age northof five weeks. She noted that his right ear had started suppurating and various lymph nodes on the neck "swelled up". In the following months, the nodes spontaneously drained or required surgical incision and drainage. His sister recalled:

"Later, my father [played], as one does with small children, ,Listen to the clock ticking' with him and he found that (my brother) couldn't hear. And then, of 


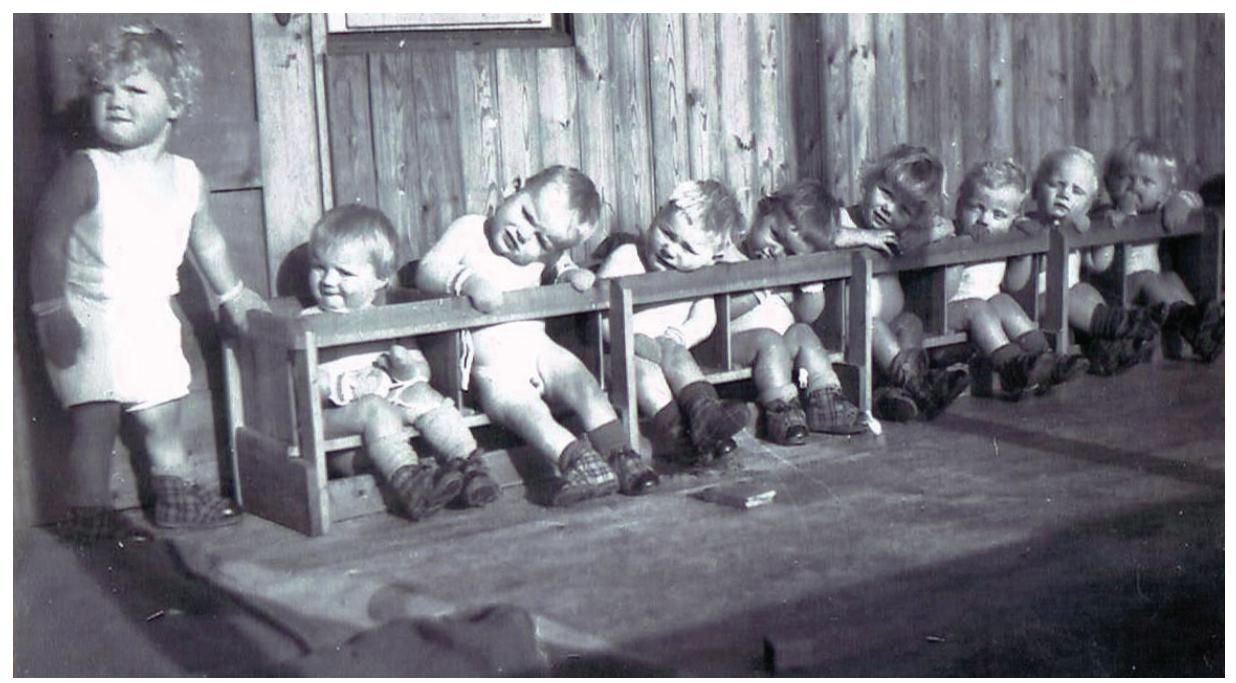

Figure 3. Views of 'Calmette Kinder' at a summer sanatorium on the North Sea in hopes of mitigating effects of tuberculosis contracted from contaminated BCG inoculation. (photography privately owned)

course, [the ear] was examined by the doctor. It was completely eroded, the ear. It was broken."

Middle ear tuberculosis as a focus of infection occurred in 21 cases of the vaccinated infants, of whom 12 survived. This rather unique focus of infection was due to either the vomiting of infectious stomach contents after the vaccination or by holding the child's nose closed during the feeding of the vaccine to force the newborn to swallow.(14) Middle ear tuberculosis led to a life-long deafness and health impairment. Another of the interviewees with similar symptoms was, like many other 'Calmette Kinder', relegated to a sanatorium in the fresh air of the North Sea near St. Peter the following summer of 1931 (Figures 3 and 5). While the otic discharge eventually stopped, he recalled the need to clean the ear daily and seal the canal with an absorbent cotton to protect against malodor. An operation became necessary when the inflammation returned in the early 1970 s followed by regular cleaning by ENT specialists. One of the most severely damaged surviving children suffered from double-sided middle ear tuberculosis. In addition to complete deafness, the infection also caused left permanent facial nerve palsy and stigmatised her for life. As an infant she could not learn to speak properly and had to attend a school for the hearing impaired far away from Lübeck. Finishing school, she was initially unable to find a job. After a court action by her mother, she finally received a guaranteed job for life in the sewing room at the Lübeck General Hospital and a pension.

\section{Compensation}

Beside the medical treatment the Lübeck government also provided comprehensive support for recovery. This included the provision of additional fat- and energy-rich foodstuffs such as milk, butter and eggs, rent subsidies and arrangement of new apartments or household support. In the difficult economic times of the early 1930s, these grants were very welcome and partly continued over several years. Funeral expenses were also covered and a portion of a Lübeck cemetery was created especially for the victims of the disaster. The partly weathered graves serve as a reminder of the devastating losses these families sustained (Figure 3).(15)

For their suffering, the 'Calmette Kinder' were meant to receive direct monetary compensation which was decided by the Lübeck government before the trial, irrespective of the verdict or the question of guilt. For this purpose, an arbitration court was established and an agreement was concluded with the majority of the parents in 1931. Children were medically examined and the severity of their illnesses was classified. Based on these medical estimates the compensation sums between 300 and 1,500 Reichsmark were considered. The money was held in 'blocked' savings books until the child reached the age of 21 . One of the consequences of the Second World War was, however, the currency reform in West Germany and, therefore, Lübeck, in 1948. All West German money, and with it, the savings books, was converted from Reichsmarks to Deutsche Marks at 
a ratio of 10:1. Reduced to 1/10th of their original value, the revaluation meant an almost complete loss of the compensation. One interviewee remembers:

"We were all somewhat cheated, the Calmette Kinder, who got compensation. My parents got 1,000 Reichsmark for me, that was at a time when the money was still Reichsmark. [It was] on a savings book, but a blocked one, I can still see [the letters] today, red: ,blocked'. My parents were only allowed to use the interest for themselves or for me, but I didn't get the money paid out until I was 21 . Well, by then, it was June 20,1948, and there was the currency [reform]. I got married eight days before [the change in] currency when I was just 18, and then I [thought]: 'Yes, now I'm married, now I get my money'. And at that point, my parents had not taken a penny from [the account], so there were supposed to be 1,390 Reichsmark in it. Afterwards, [with the reform], it was now just 139 Deutsche Marks."

\section{Parental commitment and the 'ICG'}

Aside from government support, the parents of the 'Calmette Kinder' were by no means passive but established a support group a mere five days after the announcement of the disaster. Convened by Richard Pangels, who was to lose his own child a month later (figure 2), a parents' committee was formed to jointly represent the parental interests. Members of the committee also participated in the investigation committee of the Lübeck city parliament. In 1931 a community of interest, the "Interessengemeinschaft der Calmette-Geschädigten" (Ger. "Geschädigte": injured), or ICG, was founded. Among other things, the ICG supported parents in applying for welfare benefits, organized wreath ceremonies at the cemetery, and celebrations for the surviving children and their families. One contemporary witness owned pictures of a summer party (Figure 4) and one interviewee still vividly remembered the Christmas parties of the ICG:

"Well, it started in the early afternoon. The children recited poems there and (sang) Christmas carols, we had coffee and cake, St Nicholas came, everyone got a present and so on. And then in the late afternoon, the parents came over. There was a small dance afterwards, and then, in the course of the evening, we said our hearty goodbyes. The last time was probably in 1938."

The ICG presumably dissolved during the Second World War.

\section{DISCUSSION}

By 2021, most of the interviewed former 'Calemette Kinder' have died. The oral history project was therefore the last chance to collect their memories. The interviews revealed that the Lübeck disaster and the fact of being a 'Calmette Kind' continue to have a life-long effect, even beyond the turmoil of the war, the 1942 air raids on Lübeck, and the economic devastation of the postwar period. The study revealed previously unknown details about the compensation proceedings of the arbitration court and the parental work. The fact that the compensation was devalued in 1948 first became known through the interviews, as the official documentation

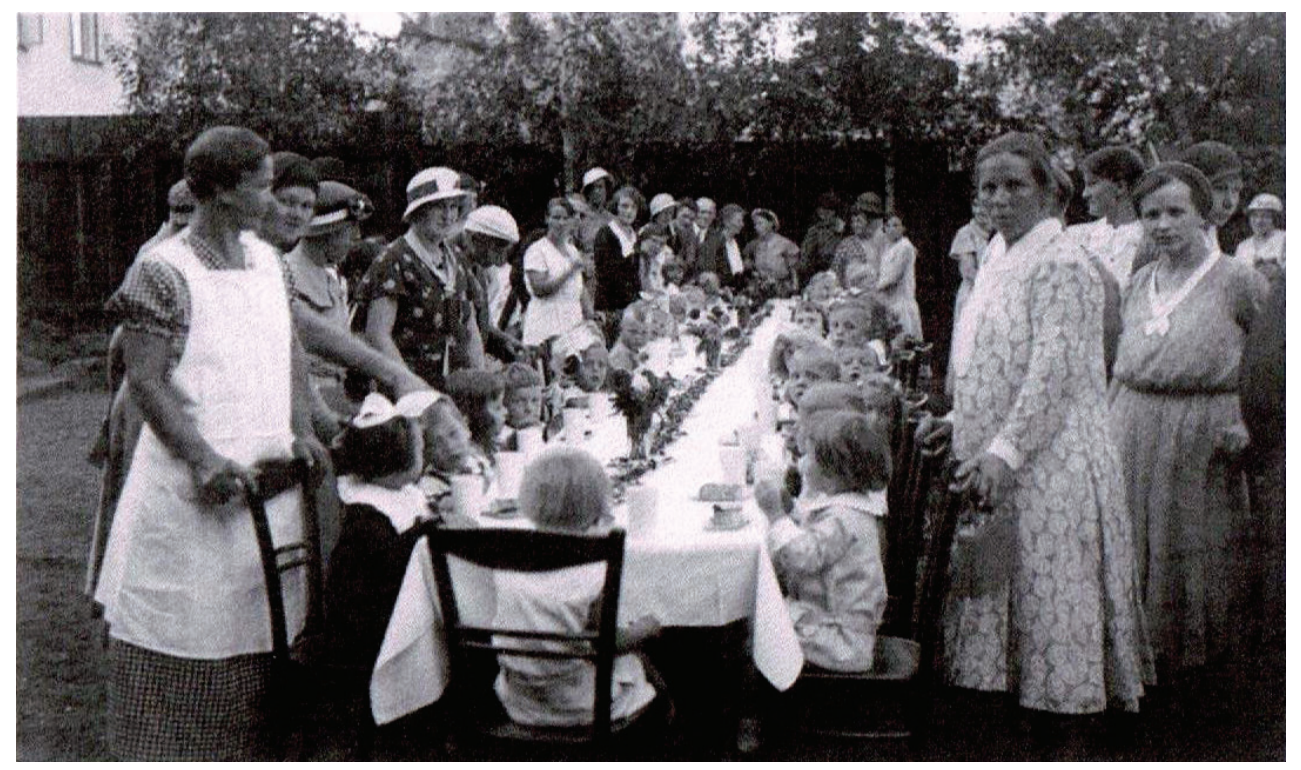

Figure 4. Summer party of the ICG, a parent-organized support group for Lübeck Disaster survivors which was active throughout the 1930s until the onset of the Second World War. (photography privately owned) 
of the city of Lübeck ended with the beginning of the Second World War.

The interviewees, at their advanced ages, offered the contemporary witness a comprehensive retrospective especially regarding diseases and lifelong health impairments and their disaster daily burden. Other survivors showed disappointment at the loss of compensation and for still others the disaster was an important aspect of their biography. This multi-layered aftermath of the 'Lübecker Impfunglück' shows how a single catastrophic event shaped the lives of not only those affected, but their relatives, their caregivers, and the convicted physicians.

The Lübeck disaster became known through the medical world and has been continued in textbooks and curricula regarding biosafety and medical ethics. Some aspects, such as that parents were never told that live, albeit attenuated, tuberculosis bacteria would be administered to their children, are inconceivable from today's perspective in the era of Informed Consent. Also, vaccine production under the conditions of that time would never be allowed today. It is precisely from such terrible mistakes like the 'Lübecker Impfunglück' that we learn and better prepare for the future. Research, in general, leads to progress with the establishment, testing, and disproval of hypotheses and pre-conceived assumptions. BCG itself, which was at once a celebrated vaccine, later turned out to have a much reduced efficacy against tuberculosis than was originally hoped. Observations by Berton Zbar and Ernesto Morales, however, demonstrated the efficacy of BCG in the fight against NIMBC, for which intravesical

\section{REFERENCES}

1. Jonas HE: Das Lübecker Impfunglück 1930 in der Wahrnehmung von Zeitzeuginnen und Zeitzeugen. Inauguraldissertation zur Erlangung der Doktorwürde der Universität zu Lübeck [The Lübeck vaccination accident in 1930 as perceived by contemporary witnesses. Inaugural dissertation to obtain a doctorate from the University of Lübeck], Lübeck, 2017.

2. Calmette A, Guerin C, Weill-Halle B: Essai d'immunisation contre l'infection tuberculeuse [Essay on the immunization against tuberculosis]. Bull Acad Med 1924; 91: 787.

3. Urteil gegen Prof. Dr. F. G. B. Deycke: Calmette-Prozess, Eigenverlag, Lübeck 1932.

4. Moegling A: Die Epidemiologie der Lübecker Säuglingstuberkulose [The Epidemiology of the infantile tuberculosis in Lübeck]. In: Die Säuglingstuberkulose in Lübeck. Zusammenfassung der anlässlich der Lübecker
BCG therapy has become a standard of care in urology world-wide.(16) Calmette and Guérin could never have guessed this new-found success of their research. The COVID 19 pandemic accelerated vaccine development to an unprecedented pace, and its long-term effects and possibly side effects, as well as those of the infection itself, cannot be surveyed at this time. Without studying and learning from uncertainty, however, medical progress is not possible. The Lübeck disaster is such a reminder that despite the lack of absolute certainty in medicine, careful, assiduous, and meticulous methods are critical for the safety and benefit of patients of times to come.

\section{CONCLUSIONS}

The risks and benefits of public vaccination programs was illustrated by the so-called BCG disaster in Lubeck, 1930. Lessons learned from the medical accident, and the private and public efforts to compensate and prevent further catastrophes lie at the basis for modern efforts to combat microbiological threats.
Säuglingserkrankungen auf Veranlassung und mit Unterstuztung des Reichsministeriums des Innern durghgefuehrten Untersuchungen. Arbeitem aus dem Reichsgesundheit, [Summary of the investigations carried out on the occasion of the Lübeck infant diseases at the request and with the support of the Reich Ministry of the Interior. Work from the Reich Health Office] Berlin: Springer 1935; 69.

5. From our Berlin Correspondent: The Lübeck Trial. Lancet 1931; 218: 927.

6. From our Berlin Correspondent: The LübeckTrial. Lancet 1932; 219: 102.

7. Report on the Infant Deaths in Lübeck. JAMA - Journal of the American Medical Association 1931; 96: 283.

8. Scherpereel P: Albert Calmette: Jusqu'à ce que mes yeux se ferment [Until my eyes are closed]. Paris: L'Harmattan 2016.

9. Lindner U: Gesundheitspolitik in der Nachkriegszeit [PostWar Politics of Health]: Großbritannien und die Bundesrepublik Deutschland im Vergleich. Munich: Oldenbourg 2004. 
10. Portelli A: What makes oral history different?. In: The oral history reader, 2nd ed. Edited by R Perks, A Thomson. London: Routledge 2006.

11. Ritchie DA: Doing oral history. Oxford: Oxford University Press, 2003.

12. Kleinschmidt $\mathrm{H}$ : Einfluß therapeutischer Maßnahmen auf den Ablauf der Lübecker Säuglingstuberkuloseerkrankungen. In: Die Säuglingstuberkulose in Lübeck. Zusammenfassung der anlässlich der Lübecker Säuglingserkrankungen auf Veranlassung und mit Unterstützung des Reichsministeriums des Innern durchgeführten Untersuchungen. Arbeiten aus dem Reichsgesundheitsamt [See Ref. 4, above], Berlin: Springer 1935; 69.

13. Kleinschmidt $\mathrm{H}$ : Untersuchungen der als Neugeborene tuberkuloseinfizierten Lübecker Kinder im Alter von 12 Jahren. Beiträge zur Klinik der Tuberkulose und spezifischen Tuberkulose-Forschung 1943; 99: 291. 14. Schürmann $P$, Kleinschmidt $\mathrm{H}$ : Pathologie und Klinik der Lübecker Säuglingstuberkuloseerkrankungen. In: Die Säuglingstuberkulose in Lübeck. Zusammenfassung der anlässlich der Lübecker Säuglingserkrankungen auf Veranlassung und mit Unterstützung des Reichsministeriums des Innern durchgeführten Untersuchungen. Arbeiten aus dem
Reichsgesundheitsamt [See Ref. 4 above] Berlin: Springer 1935; 69.

15. Fick W: Lübecker Friedhöfe: Vorwerker Friedhof. 100 Jahre von 1907-2007, Hansestadt Lübeck

[Lübeck's Cemetaries: Vorwerker Cemetary. 100 Years from 1907-2007, the Hanseatic City of Lübeck] Lübeck: Fachbereich Planen und Bauen 2006.

16. Herr HW: History of Bacillus Calmette-Guerin and Bladder Cancer: An Immunotherapy Success Story. Journal of Urology 2008; 179: 53.

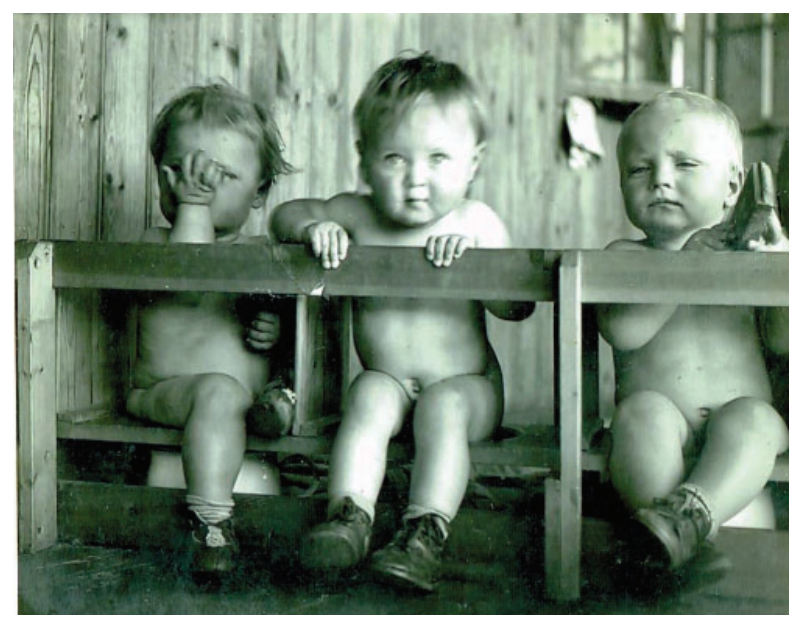

Figure 5. Calmette Kinder recovering by the North Sea, summer 1931 (photography privately owned) 